\title{
Processing of platinum group metal ores in Russia and South Africa: current state and prospects
}

\author{
Tatyana N. ALEKSANDROVA ${ }^{1}$, Cyril O'CONNOR $^{2}$ \\ ${ }^{1}$ Saint Petersburg Mining University, Saint Petersburg, Russia \\ ${ }^{2}$ University of Cape Town, Cape Town, South Africa
}

How to cite this paper: Aleksandrova T.N., O'Connor C. Processing of platinum group metal ores in Russia and South Africa: current state and prospects. Journal of Mining Institute. 2020. Vol. 244, p. 462-473. DOI: 10.31897/PMI.2020.4.9

\begin{abstract}
The presented study is devoted to a comparative review of the mineral raw material base of platinum group metals (PGMs) and technologies of their processing in South Africa and Russia, the largest PGM producers. Mineralogical and geochemical classification and industrial value of iron-platinum and platinum-bearing deposits are presented in this work. The paper also reviews types of PGM ore body occurrences, ore processing methods (with a special focus on flotation processes), as well as difficulties encountered by enterprises at the processing stage, as they increase recovery of the valuable components. Data on mineralogical features of PGM deposits, including the distribution of elements in the ores, are provided. The main lines of research on mineralogical features and processing of raw materials of various genesis are identified and validated.

Sulfide deposits are found to be of the highest industrial value in both countries. Such unconventional PGM sources, as black shale, dunites, chromite, low-sulfide, chromium and titanomagnetite ores, anthropogenic raw materials, etc. are considered. The main lines of research that would bring into processing non-conventional metal sources are substantiated.

Analysis of new processing and metallurgical methods of PGM recovery from non-conventional and industrial raw materials is conducted; the review of existing processing technologies for platinum-bearing raw materials is carried out. Technologies that utilize modern equipment for ultrafine grinding are considered, as well as existing reagents for flotation recovery; evaluation of their selectivity in relation to platinum minerals is presented.

Basing on the analysis of main technological processes of PGM ore treatment, the most efficient schemes are identified, i.e.,gravity and flotation treatment with subsequent metallurgical processing.
\end{abstract}

Key words: platinum group metals; processing technology; flotation; gravity treatment; low-sulfide ores; black shales; titanomagnetite ores; chromite ores

Acknowledgements. Research was carried out with financial support from the Russian Science Foundation (Project N 19-17-00096).

Introduction. Presently Russia and the Republic of South Africa are generally recognized world leaders in the production of platinum group metals (PGMs), which is confirmed by data on world production of platinum, palladium and rhodium in 2018, where $84 \%$ of global PGM production takes place in these two countries [17]:

$\begin{array}{lccc}\text { Production, thousand oz.: } & \text { Platinum } & \text { Palladium } & \text { Rhodium } \\ \text { South Africa } & 4.467 & 2.543 & 618 \\ \text { Russia } & 687 & 2.976 & 69 \\ \text { Other countries } & 959 & 1.458 & 70 \\ \text { Total } & 6.123 & 6.977 & 792 \\ \text { Recycling } & 2.150 & 3.124 & 371 \\ \text { Total gross demand } & 7.846 & 10.222 & 1.119 \\ \text { Total net demand } & 5.741 & 7.098 & 748\end{array}$

Global platinum production and consumption in 2017-2019 (thousand oz.):

$\begin{array}{lccc} & 2017 & 2018 & 2019 \\ \text { Production: } & & & \\ \quad \text { South Africa } & 4.450 & 4.467 & 4.565 \\ \text { Russia } & 720 & 687 & 668 \\ \text { Other countries } & 953 & 959 & 956 \\ \quad \text { Total } & 6.123 & 6.113 & 6.189 \\ \text { Consumption: } & & & \\ \text { Autocatalyst manufacture } & 3.248 & 3.051 & 3.128 \\ \text { Jewellery } & 2.400 & 2.269 & 2.229 \\ \text { Industrial } & 2.117 & 2.450 & 2.322 \\ \text { Recycling } & -2.047 & -2.150 & -2.219\end{array}$


Presented data on platinum production in 2017-2019 reflect a gradual slowdown of demand, which is explained by the reduction of platinum use in autocatalyst manufacture for diesel engines. At the same time, a widespread transition to gasoline engines caused a growing demand in palladium.

This is supported by the analysis of the London Metal Exchange (LME) prices on these two metals over the last three decades [4]. Still, these factors demonstrate that both metals will be in high demand as long as gasoline and diesel engines are used. It is also possible that jewellery and industrial applications of platinum will make it a reliable source of investment in the long term.

On a global scale, $62 \%$ of palladium is used in automobile industry. Other areas of its application are much smaller: electronics $(17 \%)$, dentistry $(8 \%)$ and jewellery $(7 \%)$. Extension of palladium applications predetermines sustainable growth of prices on this metal.

This paper provides an overview of various types of PGM ore body occurrences and methods of their treatment, with a special focus on flotation processes, as well as the difficulties encountered by enterprises at the processing stage when increasing recovery of the useful components.

Geological occurrence of ore bodies. South Africa. In South Africa, the main deposits of PGM ores are confined to the Bushveld complex, located in the north of the country. The upper zone of the complex has the highest PGM concentration. The Bushveld complex is composed of the upper group of chromium ores No.2 (UG-2), the Merensky and Platreef ore beds. The mineral ores of these reefs differ in the grain size, PGM association and concentration: ruthenium $(\mathrm{Ru})$, rhodium (Rh), palladium (Pd), osmium (Os), iridium (Ir) and platinum (Pt). According to some estimates, at current global rates of consumption, platinum reserves of the Platreef ore body will last ca. 800 years. Western limestone deposits that contain platinum-bearing ore are mostly developed with underground technique, whereas eastern ones use an open-cut one. As quarry mining is significantly cheaper than deep mining, in recent years the majority of operating companies have transitioned to the former.

Russia. Presently, Russia is one of the largest PGM producers on the global market. However, it should be taken into account that the major share of PGMs is represented by palladium, the dominant platinoid in sulfide copper-nickel ores of the Norilsk region and the Kola Peninsula, where currently $99.5 \%$ of active PGM reserves are located. In terms of total platinum production, the Russian Federation produces less than one fifth of South Africa's production volumes.In the mid-term, an increase in volumes of production and treatment of platinum ores in Russia can be achieved by bringing into processing non-conventional platinum-bearing sources. Ores with platinum-type mineralization, associated with the zonal basic and ultrabasic ore bodies in the Urals, Aldan and Kamchatka, carbon (black shale) seams in the Far East, and vanadium-iron-titanium oxidized sulfide formations in Karelia, all have the potential for platinum recovery. The source of greatest interest is platinum from low-grade ores of South-Siberian Continental Plateau with stratified ultrabasic rocks. One of the leading global PGM producers is the Russian Platinum Company. The company's assets are located in Russia and include such deposits, as Kondyor (Khabarovsk region), Chernogorskoye (Krasnoyarsk region), and southern part of Norilsk-1 (Krasnoyarsk region). It should be noted that Kondyor is the largest proved alluvial deposit of platinum in the world. According to the results of the prospectors' cooperative "Amur" in 2019, the overburden amount reached 144.6 thousand $\mathrm{m}^{3}$ (in 2018 it was 86.3), 607.4 thousand $\mathrm{m}^{3}$ of sand were washed off (950 in 2018), $249.1 \mathrm{~kg}$ of placer platinum were recovered (275.1 in 2018), and $206.1 \mathrm{~kg}$ of chemically pure platinum were produced $(228.5$ in 2018)*

The largest potential sources of platinum production are anthropogenic raw materials of Norilsk and Pechenga ore districts. All over the world the interest in non-conventional mineral re-

* 2019 Deliverables of Far Eastern branches of "Russian Platinum" (in Russian). URL https://russian-platinum.ru/ press/news/266 (date of access 15.04.2020). 
sources as promising production sources of marketable materials dramatically rises due to the depletion of rich ore deposits. In accordance with existing classification, the following types of ores are considered non-conventional raw materials: ores of unique composition with no parallels in the world practice of mineral processing; low-grade and refractory ores, commercial exploitation of which using standard techniques is inefficient and unfeasible; modern technological waste; tails and overburden rocks. Feasibility of their industrial application is based on the necessity to expand recovery of minerals, increase the complexity of their processing, improve the environmental situation in mining regions.

The most fully documented geological survey and predictive assessment of potential PGM production are presented in publication [7]. Up to this day, approaches to the solution of this problem have not been generalized and are specifically applied to various types of non-conventional commercial PGM deposits, taking into account their technological and mineralogical specifics.

In the majority of cases, the processing of non-conventional types of raw materials requires new engineering solutions. The analysis of the state demonstrates that the foundation of technological development in the area of low-grade ore processing is a complex mineralogical and engineering examination of the mineral composition, including the contrast technological properties of specific valuable components and their associations. The most important trend in this area are studies of changes in these properties in the process of mineral treatment as the main criterion of processing efficiency.

Mineralogical and geochemical classification and industrial value of iron-platinum and platinum-bearing deposits:

Mineralogical and geochemical type of deposit Sulfide Pt-Pd and Pd-Pt ores

Low-sulfidation Pt-Pd and Pd-Pt ores Complex chromite ores, primary Os-Ir-Pt ores

Titanomagnetite ores, V-Pt-Pd and V-Pd-Pt

Complex nepheline platinum -bearing ores

Complex apatite-magnetite platinum-bearing ores

Carbonaceous platinum-bearing ores

Complex gematite-magnetite platinum-bearing ores

Anthropogenic and alluvial platinum deposits

Industrial value
Maximal
Very high
Higher than average
Average
High
High
Average
(not specified)

Average
(not specified)
Average

Forecast of potential platinum placer resources is carried out basing on the information on primary platinumbearing objects, assessment of their erosion rate, and a set of data on platinum placers.

Mineralogy. South Africa. Ores in the upper zone of the Bushveld geological complex have the highest PGM concentration in the world. Formations located in the zone include upper chromatite layer No.2 (ore body UG-2), Merensky reef and platinum mineralization in the northern part of the Bushveld complex. The Merensky pegmatoidal ore body contains sulfide minerals of nonferrous metals and associated platinum group elements (PGEs). The composition of rock-forming mineralization of the ore bodies is of special importance for the subject of this article. The Merensky ore bearing zone is primarily composed of orthopyroxene $(\sim 60 \%)$, plagioclase feldspar ( $20 \%$ ), pyroxene $(\sim 15 \%)$, phlogopite $(5 \%)$, and a small fraction of olivine (Fig. 1$)$. Secondary minerals, such as talc, serpentine, chlorite and magnetite, are widely spread. Base metal sulfides are predominantly composed of pyrrhotine $(\sim 40 \%)$, pentlandite $(\sim 30 \%)$ and chalcopyrite $(\sim 15 \%)$. The base minerals of platinum group are cooperite $(\mathrm{PtS})$, braggite $(\mathrm{Pt}, \mathrm{Pd}) \mathrm{NiS}$, sperrylite alloys $\left(\mathrm{PtAs}_{2}\right)$ [21]. UG-2 ore body is mainly composed of chromite (60-90\% of volume) with less silicate minerals $(5-30 \%$ of pyroxene and $1-10 \%$ of plagioclase). Other minerals, represented in smaller 


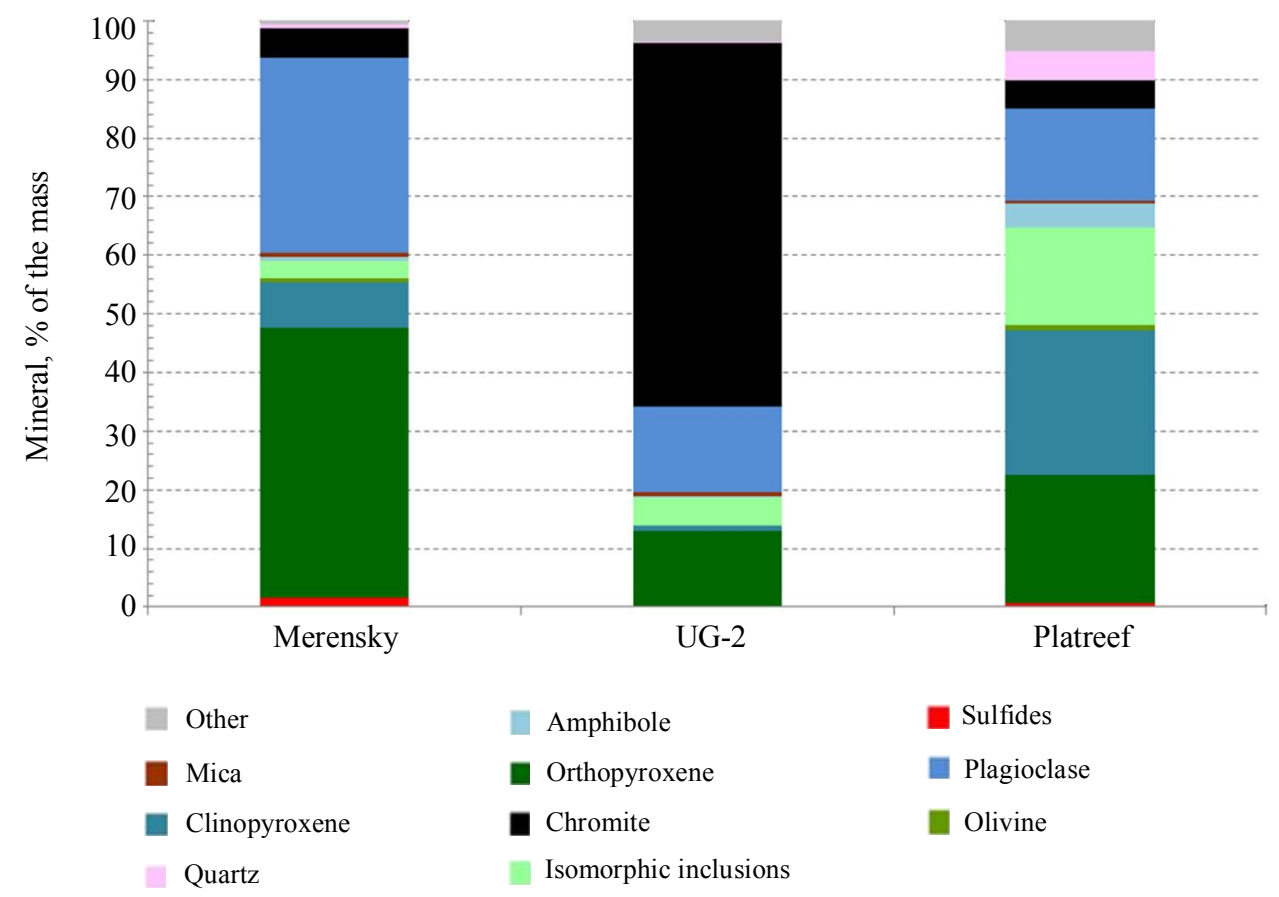

Fig.1. Distribution of base minerals in the ore bodies

concentrations, can include silicates and oxides, as well as sulfides of non-ferrous metals. Secondary minerals are represented by quartz, serpentine, and talc. $\mathrm{Cr}_{2} \mathrm{O}_{3}$ content in the UG-2 ore body lies in the interval of 30-55 \%. The total PGE content depends on the region, but on the average it equals to 4-7 g/t. PGEs in the UG-2 ore body are quite variable, but in general PGM sulfides, such as laurite $\left(\mathrm{RuS}_{2}\right)$, cooperate $(\mathrm{PtS})$ and braggite $(\mathrm{Pt}, \mathrm{Pd}) \mathrm{NiS}$, are characteristic of the ore body. Sulfides of non-ferrous metals are primarily represented by chalcopyrite, pentlandite and pyrrhotine. The platinum-bearing ore zone Platreef is located in the northern part of the Bushveld complex. This zone is a complex combination of rocks, the most numerous of which are pyroxenites, serpentinites and calcium-silicates. Dominating minerals - PGE carriers in this region are PGE tellurides, alloys, arsenides, and sulfides. Pt and Pd tellurides are the most important among those; their share of total PGEs in the ore varies from 20-30 to $45 \%$. They are followed by alloys (26\%), arsenides $(21 \%)$ and sulfides (19\%) [21].

Distribution of PGE carrying minerals in various ore zones of the Bushveld geological complex:

$\begin{array}{lccccc}\text { Ore body } & \text { Sulfides } & \text { Tellurides } & \text { Arsenides } & \text { Alloys } & \text { Other } \\ \text { Merensky } & 36 & 30 & 7 & 7 & 20 \\ \text { UG-2 } & 70 & <5 & <5 & 20 & <5 \\ \text { Platreef } & 3 & 30 & 21 & 26 & 20\end{array}$

Russia. In solid ores PGE concentration depends on the mineral composition [1]. Pyrrhotine ores have a relatively stable composition $(\mathrm{g} / \mathrm{t})$ : palladium - 7-9; platinum - 1.5-2; rhodium - 0.6-1.2; ruthenium $-0.2-0.3$; iridium $-0.06-0.10$; osmium $-0.03-0.05$. $\mathrm{Pt} / \mathrm{Pd}$ ratio equals $0.23-0.35$, ratio $(\mathrm{Pt}+\mathrm{Pd}) /(\mathrm{Rh}+\mathrm{Ir}+\mathrm{Ru}+\mathrm{Os})$ is $1-20, \Sigma \mathrm{PGE} / \mathrm{C}=0.4$. Rhodium content is sometimes comparable to that of platinum. In talnakhite and mooihoekite ores palladium and platinum content increases quickly, whereas concentration of rare platinoids decreases. $\mathrm{Pt} / \mathrm{Pd}$ ratio equals $0.24-0.30$, $(\mathrm{Pt}+\mathrm{Pd}) /(\mathrm{Rh}+\mathrm{Ir}+\mathrm{Ru}+\mathrm{Os})$ is $285-470, \Sigma \mathrm{PGE} / \mathrm{C}=1.8-4.2$. Cubanite ores have the following PGE content: palladium - 19-23; platinum - 3.4-4.9; ruthenium - 0.09-0.14; rhodium - 0.05-0.10; iridium - 0.01-0.08; osmium - 0.01-0.08 g/t, Pt/Pd ratio equals 0.23-0.24. Impregnated ores, calculated on $100 \%$ sulfide basis, have relatively high PGE content. Absolute concentrations of these ele- 
ments in the impregnated ores are the following: palladium - 3-5; platinum - 0.4-1.5; rhodium 0.02-0.14; iridium - 0.003-0.06 g/t; Pt/Pd ratio equals 0.25-0.35. Impregnated ores contain PGE with a $(\mathrm{Pt}+\mathrm{Pd}) /(\mathrm{Rh}+\mathrm{Ir}+\mathrm{Ru}+\mathrm{Os})$ ratio in the interval 7.6-22.4, $\Sigma \mathrm{Pt} / \mathrm{S}=0.8-1.9$ (see the Table).

Average PGE content in the ores of Oktyabrskoye deposit (Norilsk), g/t

\begin{tabular}{l|l|c|c|c|c|c|c}
\hline \multicolumn{1}{c|}{ Ore type } & \multicolumn{1}{c|}{ Mineral } & Pt & Pd & Rh & Ir & $\mathrm{Ru}$ & Os \\
\hline Pyrrhotine & Pyrrhotine (hexagonal) & 9 & 6.4 & 1.62 & - & 0.07 & 0.5 \\
& Pyrrhotine (monoclinic) & 0.3 & 2.4 & 1.5 & - & - & - \\
Pyrrhotine & Pentlandite & - & 49 & 0.49 & 0.06 & 0.06 & 0.04 \\
Chalcopyrite & & 8.1 & 61 & 0.03 & - & 0.09 & 0.05 \\
Cubanite & & 71 & 265 & 1.3 & 0.2 & 1.3 & 0.04 \\
Pyrrhotine & Chalcopyrite & - & - & 0.02 & - & 0.13 & 0.03 \\
Chalcopyrite & & - & - & 0.07 & - & 0.12 & 0.08 \\
Cubanite & & - & - & 0.01 & - & - & -
\end{tabular}

After the Bushveld complex, Norilsk platinoid-nickel deposit has the second highest PGE concentration in the world. The difference is that palladium prevails over platinum, while rare platinoids, same as at the Bushveld deposit, play a subordinate role compared to palladium and platinum. General distribution of platinum metals in Norilsk-1 intrusion is as follows: $\mathrm{Pd}>\mathrm{Pt}>\mathrm{Rh}>\mathrm{Ru}>\mathrm{Ir}$. Norilsk copper-nickel ores are characterized by high PGE content. According to data from papers $[8,13]$, more than $98 \%$ of these elements were recovered in the USSR: approximately $31 \mathrm{t}$ of platinum metals were annually produced at the Norilsk production facility. According to paper [14], this produce was equivalent to PGE recovery at the Bushveld complex. Norilsk deposit is the world's third biggest source of sulfide copper-nickel ores after Sudbury (Canada) and Jinchuan (China). In contrast to sulfide-nickel ores from deposits associated with komatiites, here copper-nickel ratio significantly exceeds 1 , varying from 0.9 to 2.5 , in continuous sulfide ores of the Upper-Talnakh deposit.

In the impregnated and solid ores of Norilsk, a large amount of palladium (90-95\%) is represented in the form of pentlandite, where its concentration reaches 50-1000 g/t. In pyrrhotine and chalcopyrite, its concentration does not exceed $0.1 \mathrm{~g} / \mathrm{t}$. In impregnated ores, platinum concentration in pyrrhotine and pentlandite does not exceed $1.2 \mathrm{~g} / \mathrm{t}$.

Technological schemes of flotation treatment. South Africa. Currently, in South Africa, a huge variety of flotation schemes are used to process ores of different mineral origin. Fig.2 presents an example of a traditional flow chart of ore treatment using flotation. The majority of schemes represent two-stage milling followed by the flotation process in order to avoid over-grinding. Concentrates from rougher flotation usually get through several cleaning operations. The latest trend is to apply larger flotation cells (e.g., TankCell OK-150). Due to deteriorating ore quality and growing amounts of finely impregnated ores, there is a demand for finer grinding using grinding mills of IsaMill type.

Fig.3 presents flow charts of applying grinding mills of IsaMill type in inert and ultrafine grinding.

Inert grinding is applied to improve valuable component recovery due to better grain liberation in the inert environment. The main purpose of inert grinding is to improve recovery of valuable components in the flotation circuit taken as a whole.

Ultrafine grinding allows to improve processing indicators due to better grain liberation, cleaning of the mineral surface, and enhanced selective separation of gangue from the valuable components. The main purpose of ultrafine grinding is to increase the grade of ore grinding without losing valuable components at the stage of scavenging. The main particle size distribution obtained after grinding in an inert media is $80 \%$ particle size from $75-150$ to $45-60$ microns; for ultrafine grinding $80 \%$ particle size varies from $40-80$ to $15-25$ microns. 


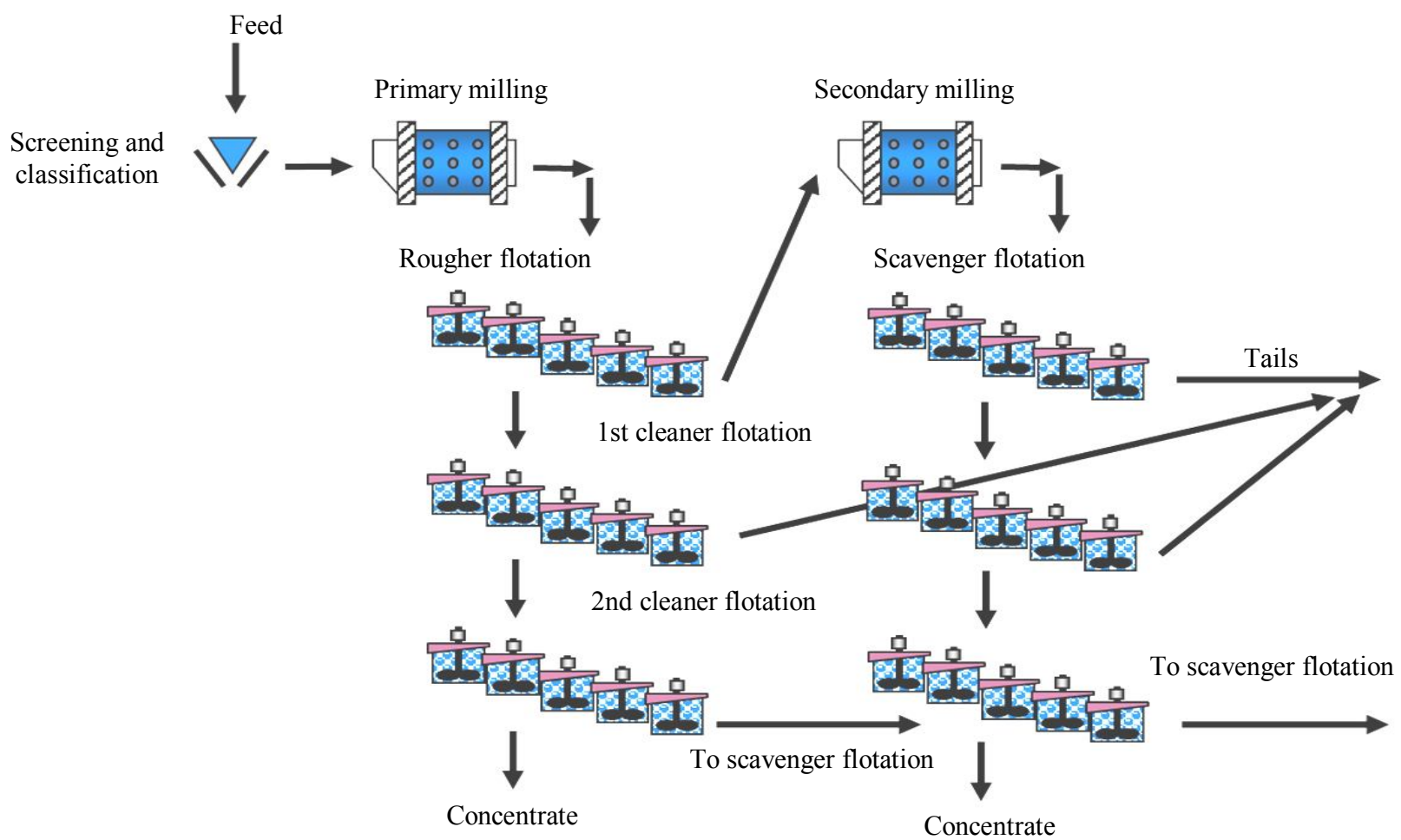

Fig.2. Traditional flow chart of flotation processing of PGM-containing ores (South Africa)

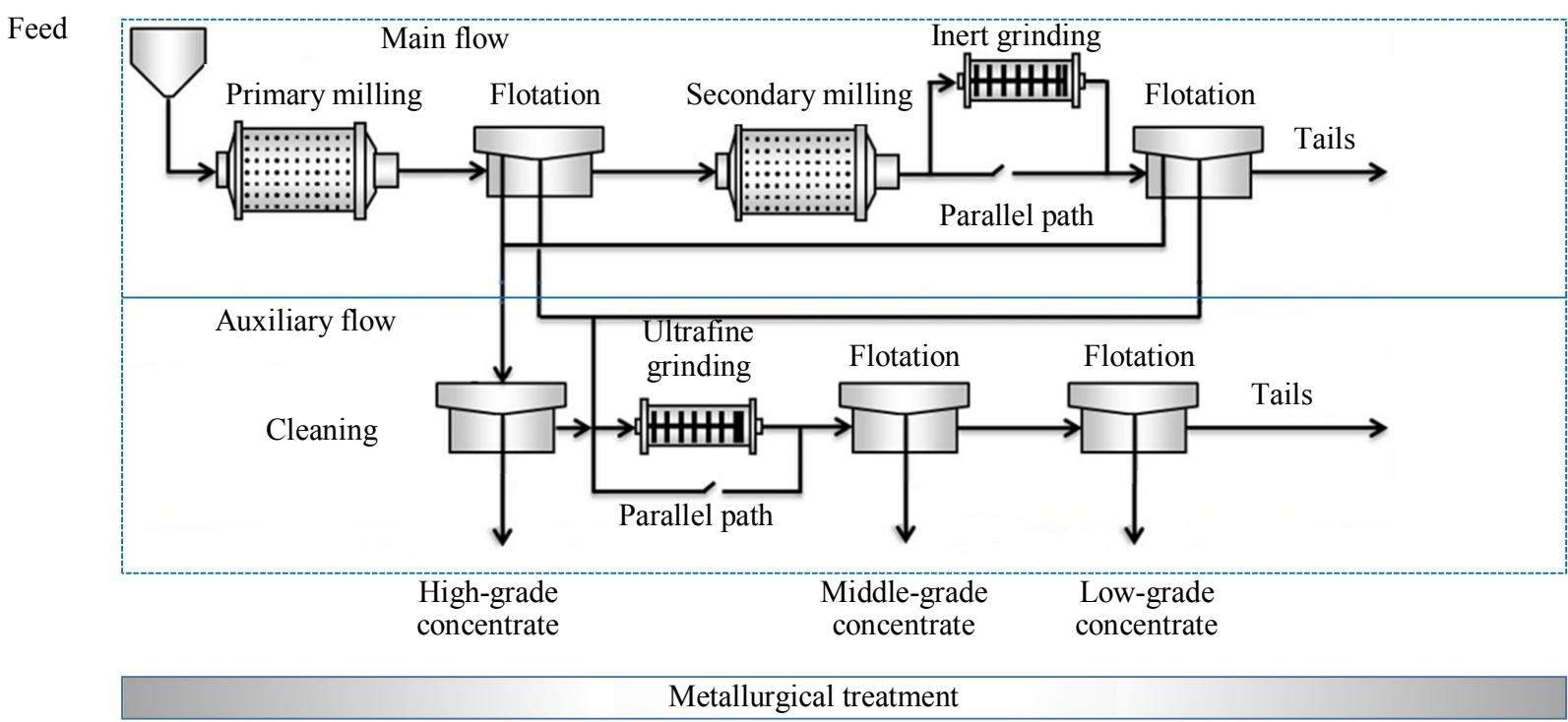

Fig.3. Flow charts of inert and ultrafine grinding application in the cycle of PGM ore processing [14]

Russia. Processing plants in Norilsk and Talnakh utilize various schemes of flotation ore treatment depending on the ore type. Application of bulk-selective flotation schemes for the treatment of impregnated and cupreous ores at Norilsk processing plant allows $85-90 \%$ of the material to exit as tails in the early stages of the process. According to this technology, the first stage of the process involves bulk flotation in order to separate sulfide minerals from the gangue, followed by selective flotation, which produces copper and nickel concentrates. In order to process impregnated ores at Norilsk-1 deposit, the technology was modified by adding a stage of gravity treatment on centrifugal Knelson concentrators, which allows to increase noble metal recovery and obtain high-grade gravity concentrate $[5,6]$. 


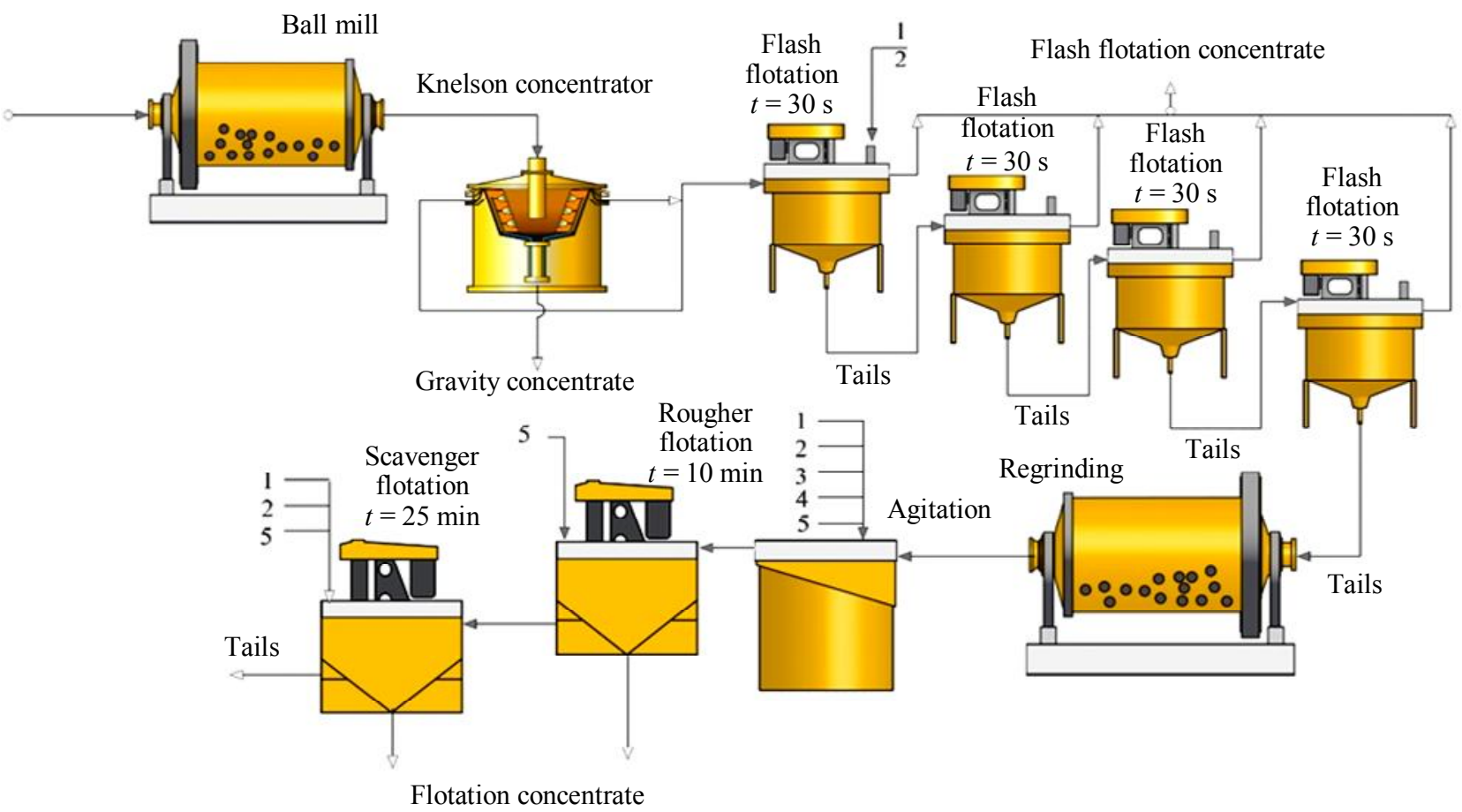

Fig.4. Flow chart of gravity and flotation treatment of sulfide ores using flash flotation $1-5$ are flotation reagent feeding points

The use of gravity and flotation scheme also demonstrates its efficiency in the processing of lowcontent sulfide ores as, despite very low content of base metals, these ores have relatively high PGM concentration. PGM losses in the tails depend on the ore type and utilized processing schemes. At the Talnakh processing plant, sulfide ores are treated using a bulk-selective scheme, because processing of rich ores is characterized by a relatively low share of tails (not higher than 25-30\%). A distinctive feature of the scheme is production of pyrrhotine concentrate, which significantly reduces the costs of metallurgical treatment [16].

Another promising scheme utilizes flash flotation, which allows to increase recovery of platinoids (Fig.4). Compared to flotation and gravity treatment, the application of this scheme allows to increase recovery of platinum and palladium by 3.22 and $4.1 \%$, respectively.

Reagent scheme of flotation and gravity treatment:

Reagent feeding point

Reagent designations

Reagent consumption, $\mathrm{g} / \mathrm{t}$ :

Flash flotation

Rougher flotation

Scavenger flotation
1

Butyl xanthate

30

25

45

$\begin{array}{cccc}2 & 3 & 4 & 5 \\ \text { Butyl aerofloat } & \text { DP-4 } & \text { Copper sulfate } & \text { T-80 } \\ & & & \\ - & - & - & 10 \\ 35 & 10 & 10 & 10 \\ 25 & - & - & 5\end{array}$

Fig.5 presents results of gravity and flotation treatment of sulfide ores using flash flotation. Data analysis allows to come to a conclusion that at the flotation stage clean concentrate maximizes the concentration of platinum metals; effective concentration of minerals, both platinum and palladium, is also observed in the flash flotation circuit. Flash flotation was carried out on SKIM-AIR flotation units after centrifugal concentration. This technology allows to recover up to $92 \%$ of platinum and up to $87 \%$ of palladium. 


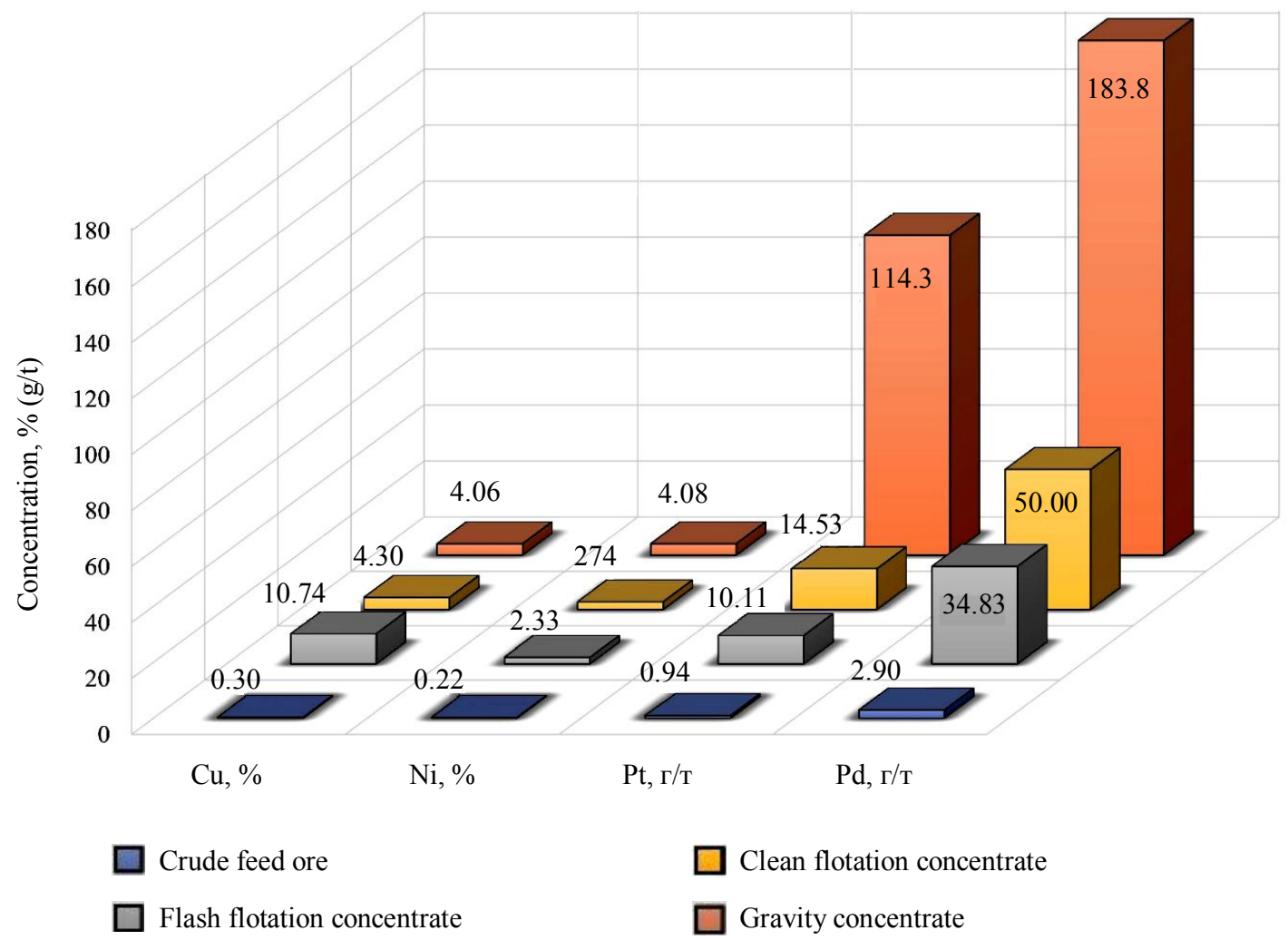

Fig.5. Results of gravity and flotation treatment of sulfide ores using flash flotation

Flotation treatment: reagent scheme and technological factors. South Africa. As a rule, sulfide flotation is performed at $\mathrm{pH} \mathrm{8-9,} \mathrm{this} \mathrm{pH}$ value is natural for Bushveld polymetallic ores. A wide range of collectors, depressants and foaming agents is used for flotation treatment of polymetallic ores. Collectors, most frequently used for flotation treatment of PGM-containing ores, are xanthogenates and dithiophosphates. The agent, most widely applied for gangue depression, is carboxymethyl cellulose (CMC). It is well known that copper sulfate is an activator used in flotation treatment of numerous sulfide and platinum group minerals. However, excessive addition of blue vitriol can increase gangue recovery $[22,24]$. The main losses in the processing of Bushveld polymetallic ores occur during separation of siliceous rock-forming minerals from mineral concentrators of valuable components, including sulfide minerals. Thus, at this deposit flotation treatment is the main method of ore processing due to similar flotation properties of PGM mineral concentrators and sulfide minerals.

Russia. Analysis of literature references allows to draw a conclusion about the similarity of main engineering solutions related to the processing of platinum-bearing ores in Russia and South Africa. Hence, for sulfide ores, the main collectors are xanthogenates and aerofloats, for depression purposes cellulose derivatives and organic depressants are used. For oxidized ores, a sulfidizer (sodium sulfide) is added to activate the surface of minerals and to generate an adsorption layer on the mineral surface for chemisorption of utilized collectors. A substitution of butyl aerofloat for isobutyl one, traditionally used at Norilsk processing plant, allowed to increase recovery of both non-ferrous and noble metals. One of the main technological distinctions is the use of BF-4 agent, due to its insolubility fed as a $5 \%$ emulsion in diesel oil. Implementation of all the above-mentioned features led to a significant improvement in performance parameters of impregnated ore processing in Norilsk and Talnakh. 
Processing of PGM ores. South Africa. Four main growth areas are associated with the flotation treatment of PGM ores: processing of chromites, processing of tellurides and arsenides, fine particle flotation, and utilization of effective depressants for gangue minerals.

Chromites. The UG-2 ore body contains substantial quantities of chromite, comprising 20-60\% of the entire mass at $\mathrm{Cr} / \mathrm{Fe}$ ratio of 1.35 [15]. The main ore mineralization is presented by sulfide minerals, including pyrrhotine, pentlandite, and chalcopyrite [19]. Due to high concentration of chromite in the feed ore, in the flotation process a part of it is recovered as concentrate. This significantly complicates metallurgical processing, as chromite belongs to the spinel group of minerals and produces forms stable at $2000{ }^{\circ} \mathrm{C}$.

The maximal concentration of chromite in the flotation concentrate, which enters the metallurgical processing stage, is around $3 \%$. Chromite is by nature strongly water-wet, which predetermines its flotation properties. Froth recovery of chromite is primarily related to mechanical overflow; however, up until now the problem of unintended chemical activation of chromite has not been properly studied. In order to lower the content of chromite in the concentrate, it is possible to utilize gravity separation and to reduce water recovery in the flotation process, which will result in reduced mechanical outflow.

Processing of tellurides and asenides. Studies, dedicated to flotation of synthetic tellurides, arsenides and sulfides of platinum and palladium, demonstrate that the use of sodium isobutyl xanthogenate leads to their froth recovery. However, whereas for sulfide minerals addition of an activator, e.g., copper sulfate, leads to increased concentrate recovery, for tellurides and arsenides, especially for $\mathrm{PtTe}_{2}$ and $\mathrm{PtAs}_{2}$, the concentrate recovery decreases. It is assumed that these minerals float due to dixanthogenide. The presence of copper sulfate may slow down xanthogenate decomposition. The negative effect of copper on the recovery may be associated with copper oxide settling on mineral surface, which can result in a decreased adsorption of xanthogenate. The identification of selective collectors for tellurides and arsenides is a topical question.

Fine particle flotation. The presence of fine classes is a problem for flotation treatment. Fine particle aggregation can have a beneficial effect on performance parameters, especially at low $\mathrm{pH}$ values. With rising $\mathrm{pH}$ level hydroxide ions settle on the surface of minerals and reduce the possibility of their aggregation. Fine classes are also more prone to oxidation, so for them, inert grinding can be recommended, e.g., using grinding mills of IsaMill type. Apart from reducing oxidation, inert grinding can also increase flotation rate and performance due to additional cleaning of the surface from talc and iron hydroxides.

Effective depressants for gangue minerals. One of the main problems of PGM mineral flotation is the control and management of flotation properties of gangue minerals, usually composed of silicates, such as orthopyroxene, feldspar, plagioclase, and pyroxene. Often these minerals intergrow with talc, which increases their floatability due to its natural water repellency. The most widely used depressant is CMC. Due to PGM association with sulfide minerals, copper sulfide, utilized as an activator of these minerals, can reduce $\mathrm{PtTe}_{2}$ recovery, the share of which in the Platreef ore body reaches up to $40 \%$. Depressants also affect the froth layer, reducing its stability by decreasing the froth recovery of the solid phase. This negative effect can be minimized by the increasing consumption of foaming agents and the utilization of solutions with greater ionic strength.

Russia. The main development trends of the PGM ore treatment are associated with the processing of new PGM sources, development and adoption of engineering solutions for ore preparation and treatment that take into account the mineral composition of the ores.

Black shales. Black shale deposits are a promising source of noble metals. An important aspect here is the examination of their mineralization specifics and their differentiation into a separate black shale, or carbonaceous, formation. Practically all PGMs have been discovered in gold deposits of this type - not only platinum, but also palladium, iridium, ruthenium, and rhodium. It can be 
stated that abundant presence of PGMs is typical for these deposits, which not only confirms the feasibility of their processing as objects of gold-platinum black shale formations, but also significantly increases the practical value and profitability of their development. Today it is especially important, as it allows to review black shales as a promising non-conventional source of platinum metals. Recently a lot of attention has been paid to the assessment of platinum oxide concentration in large high-grade gold-containing deposits of the black shale formation (Sukhoy Log, Natalka, etc.). Such issues as formation conditions of black shale layers and specifics of their mineralization genesis are actively discussed, because this type of deposits has never been properly examined, which complicates effective prospecting and estimation of their potential. There is no general consensus on the forms of noble metal presence in this type of ores and the choice of methods to estimate PGM concentration in iron oxides and hydroxides, clay, mica, chlorites, alunite, quartz-chalcedony, jarosite, and a number of other mineral concentrators, as well as coal-bitumen inclusions in the shale. Potentially, platinum-bearing black shales are widely spread in the Riphean-Paleozoic carcass of the Siberian platform, South Verkhoyansk fold zone, Salemdzhino-Kerbinsky and Nilsky structural formations of the Amur-Okhotsk fold system, and Late Precambrian and Cambrian foredeep basins of the Bureya massif.

Mineral and technological studies were performed on black shale samples from the Bureya massif. Platinum is most likely associated with graphite and occurs in an ultradispersed form. Its recovery using gravity treatment remains at the level of $11.9 \%$, whereas flotation methods can increase it up to $88.1 \%$. Research results confirm the presence of a large-scale commercially productive mineralization of gold, associated with platinum mineralization in carbonate rocks of the Bureya massif $[9,12$, 18]. The examined black shale objects are a source of new complex mineralization of noble metals, which is currently understudied and is not involved in the commercial development. Studies on the processability of mineral raw materials demonstrated that in principal it is possible to obtain marketable graphite concentrates, including ones with a high content of noble metals, using gravity and flotation treatment and subsequent pyro- and hydrometallurgical processing.

Titanomagnetite ores. Titanomagnetite ores, including the ores from Pudogorsky and Koykarsky deposits in Karelia, can be promising PGM sources that contain high concentrations of noble metals. For the ores from Koykarsky deposit, the following concentrations were estimated, \%: iron $(\mathrm{Fe})-22.3$; titanium dioxide $\left(\mathrm{TiO}_{2}\right)-6.15$; vanadium pentoxide $\left(\mathrm{V}_{2} \mathrm{O}_{5}\right)-0.32$; copper $(\mathrm{Cu})-0.13$; a sum of platinum, palladium and gold $(\mathrm{Pt}+\mathrm{Pd}+\mathrm{Au})-1.4 \mathrm{~g} / \mathrm{t}$. At the Pudogorsky deposit, the concentrations are quite similar, $\%$ : $\mathrm{Fe}-28.9 ; \mathrm{TiO}_{2}-8.14 ; \mathrm{V}_{2} \mathrm{O}_{5}-0.43 ; \mathrm{Cu}-0.13 ; \mathrm{Pt}+\mathrm{Pd}+\mathrm{Au}-$ $0.923 \mathrm{~g} / \mathrm{t}$.

The ore processing at the Pudogorsky deposit is performed using the following scheme: after the preparation stage, the ore undergoes magnetic separation resulting in the production of ferrotitanium concentrate (yield $30 \%$, iron recovery $-64 \%$; $\mathrm{TiO}_{2}-61 \% ; \mathrm{V}_{2} \mathrm{O}_{5}-70.5 \%$ ); for tails it is planned to utilize the sulfide flotation with several cleaning stages resulting in the production of copper-noble-metal concentrate.

Calculations made by individual researchers show that in a complex approach to the development of titanomagnetite ore processing technology, recovery costs of noble metals can exceed those of the base component. After grinding, it is suggested to perform sulfide flotation and obtain copper concentrate with high gold and PGM content with subsequent magnetic treatment of the tails and production of the ferrotitanium concentrate. As a result, it is possible to increase extraction of platinum into the copper concentrate up to $70-90 \%$ with a minor decrease (by $1-3 \%$ ) in the recovery and quality of the iron concentrate.

Low-sulfide ores. The main sources of the PGM extraction in Russia and worldwide are layered ultrabasite-basite massifs, containing unique deposits of copper-nickel sulfide ores. The presence of high platinum concentrations in sulfide ores and close relationship between the ore genesis 
and processes of magmatic melt differentiation allow to suggest that the formation of high PGM concentrations in stratified intrusions can only occur from the position of a sulfide model. However, in certain stratified ultrabasite-basite massifs, localized in the fold carcass of the Siberian platform, high PGM concentrations are combined with a relatively low sulfide content or lack thereof. The Yoko-Dovyrensky and Chineysky plutons belong to the peridotite-pyroxenite-anorthosite-gabbroid type of magmatic formations and can be compared to platinum-bearing stratified massifs of the ancient platform regions (Stillwater and Bushveld). The Yoko-Dovyrensky mineralization is a lowsulfide PGM massif, whereas the Chineysky deposit is a platinum-bearing formation of titanomagnetite [9].

So far, long-term geological explorations in the massifs helped to identify the general trends and typomorphic specifics of unique platinum deposits, which can have a great practical value [12, 20, 23]. Recovery of platinum ores from non-conventional sources (black shale, limestone, uranium, etc.) requires justification of its economic feasibility. In addition, it is necessary to perform detailed research on the possibility to recover valuable components using various processing methods. Otherwise, data on elevated PGM concentration in the ores from which it is impossible to recover enriched concentrates (from $100 \mathrm{~g} / \mathrm{t}$ to $1 \mathrm{~kg} / \mathrm{t}$ ) should be regarded only as geochemical characteristics of these deposits.

Conclusions. The paper presents a comparative review of the mineral raw materials base of PGMs and the main technologies of their processing in South Africa and Russia - the largest PGM producers. It was identified that sulfide deposits have the greatest commercial value in both countries.

The main improvement areas for PGM raw materials base and technologies of their processing are the following:

- restructuring of PGM resource base - processing of low-sulfide ores, PGM recovery from chromite-containing ores and anthropogenic raw materials, recovery of associated PGMs while processing chromium and oxidized nickel ores;

- data collection on proved PGM reserves;

- increased PGM recovery from processing of sulfide ores and concentrates;

- development of new processing and metallurgical methods of PGM recovery for treatment of non-conventional and industrial raw materials.

Analysis of the main technological processes in PGM ore treatment demonstrated that the most efficient schemes were gravity and flotation treatment with subsequent metallurgical processing.

\section{REFERENCES}

1. Agafonov L.V. The Problem of Platinum-Bearing Ultrabase and Base Rocks Belonging to Different Formations (Different Ultrabasite-Basite Associations). Geologiya i genezis mestorozhdenii platinovykh metallov: sbornik nauchnykh trudov, 1994, p. 189197 (in Russian).

2. Gurskaya L.I. Platinum Metal Mineralization of Black Shales and Criteria of Their Identification. St. Petersburg: VSEGEI, 2000, p. 208 (in Russian).

3. Dodin D.A., Chernyshov N.M., Yatskevich B.A. Platinum Metals Deposits of Russia. St. Petersburg: Nauka, 2000, p. 754 (in Russian).

4. London Metal Exchange, charts, prices. URL: www.lme.com/en-GB/Metals/Precious-metals/Platinum (date of access 15.04.2020).

5. Naftal M.N., Shestakova R.D. Platinum-Bearing Pyrrhotine Concentrates of Norilsk - a New Approach to the Problem of Complex Processing. Tsvetnye metally. 2001. N 6, p. 43-48 (in Russian).

6. Khramtsova I.N., Baskaev P.M., Kaitmazov N.G., Naftal M.N., Volyanskii I.V., Alekseeva L.I. Main Trends of Improvement for Technologies of Sulfide Copper-Nickel Ore Processing at Polar Branch of MMC "Nornickel". Tsvetnye metally. 2005. N 10, p. 58-63 (in Russian). 
7. David A.D., Dodina T.S., Zoloev K.K., Koroteev V.A., Chernyshov N.M. Russian Platinum: State-of-the-Art and Prospects. Litosfera. 2010. N 1, p. 3-36 (in Russian).

8. Dodin D.A., Vishnevskii A.N., Gulin S.A., Kavardin G.I. Problems of Minerageny in the Arctic. Geologiya $i$ geofizika. 1994. Vol. 35. N 9, p. 78-90 (in Russian).

9. Khanchuk A.I., Berdnikov N.V., Cherepanov A.A., Konovalova N.S. Finely-Dispersed Gold and Platinoids in Graphite Shales of the Bureya Massif - a New Type of Noble Metal Mineralization in the Russian Far East. Gornyi informatsionnoanaliticheskii byulleten (nauchno-tekhnicheskii zhurnal). 2009. Vol. 5. N 12, p. 9-18 (in Russian).

10. Chernyshov N.M. Gold-Platinum Metal Mineralization of Black Shale Type in the Kursk-Voronezh Region (Central Russia). Voronezh: Izdatelsko-poligraficheskii tsentr Voronezhskogo gosudarstvennogo universiteta, 2007, p. 177 (in Russian).

11. Chernyshov N.M. Platinum-Bearing Formations of Kursk-Voronezh Region. Voronezh: Izdatelsko-poligraficheskii tsentr Voronezhskogo gosudarstvennogo universiteta, 2004, p. 448 (in Russian).

12. Aleksandrova T.N., Talovina I.V. Platinum-group metals in residual soils and potential efficiency of their processing in gravity concentrators. Journal of Mining Science. 2017. Vol. 53. N 3, p. 553-558. DOI: 10.1134/S106273911703250X

13. Drago R., Wooden M. The determinants of labor absence: Economic factors and workgroup norms across countries. ILR Review. 1992. Vol. 45. Iss. 4, p. 764-778. DOI: 10.1177/0019793399204500411

14. Rule C.M., Knopjes L., Clermont B., Philippe C. Fine grinding - Developments in ceramic media technology and resulting improved plant performance at Anglo Platinum. Proceedings of the Third International Platinum Conference "Platinum in transformation". The Southern African Institute of Mining and Metallurgy. 2008, p. 53-62.

15. Liddell K.S., Dunne R.C., McRae L.B. Process routes for beneficiation of noble metals from Merensky and UG-2 ores. Mintek Review. 1986. N 4, p.33-44.

16. Malysiak V., Shackleton N.J., O'Connor C.T. An investigation into the floatability of a pentlandite-pyroxene system. International Journal of Mineral Processing. 2004. Vol. 74. Iss. 1-4, p. 251-262. DOI: 10.1016/j.minpro.2004.01.001

17. Matthey J. PGM Market Report February 2019. Hertfordshire, United Kingdom, 2019, p. 42.

18. Khanchuk A.I., Rasskazov I.Yu., Aleksandrova T.N., Komarova V.S. Natural and technological typomorphic associations of trace elements in carbonaceous rocks of the Kimkan noble metal occurrence, Far East. Russian Journal of Pacific Geology. 2012. Vol. 6. N 5, p. 339-348. DOI: 10.1134/S181971401205003X

19. O'Connor C.T., Shackleton N.J. Investigations into the recovery of platinum group minerals from the platreef ore of the Bushveld Complex of South Africa. Platinum Metals Review. 2013. N 57 (4), p. 302-310.

20. Lavrik N., Litvinova N., Aleksandrova T., Stepanova V., Lavrik A. Platinum mineralization comparative characteristics of the some Far East deposits: Problems of complex development of georesources electronic resource. E3S Web of Conferences. 2018. Vol. 56. 04017. DOI: 10.1051/e3sconf/20185604017

21. Schouwstra R.P., Kinloch E.D., Lee C.A. A short geological review of the Bushveld Complex. Platinum Metals Review. 2000. N 44 (1), p. 33-39.

22. Shackleton N.J., Malysiak V., O’Connor C.T. The use of amine complexes in managing inadvertent activation of pyroxene in a pentlandite-pyroxene flotation system. Minerals Engineering. 2003. Vol. 16. Iss. 9, p. 849-856. DOI: 10.1016/S0892-6875(03)00215-2

23. Talovina I.V., Alexandrova T.N., Lieberwirth H., Heide G. Supergene oxide-silicate nickel deposits: mineral-geochemical composition and peculiarities of processing. Eurasian Mining. 2017. N 1, p. 21-24. DOI: 10.17580/em.2017.01.06

24. Wesseldijk Q.I., Reuter M.A., Bradshaw D.J., Harris P.J. The flotation behaviour of chromite with respect to the beneficiation of UG2 ore. Minerals Engineering. 1999. Vol. 12. Iss. 10, p. 1177-1184. DOI: 10.1016/S0892-6875(99)00104-1

Authors: Tatiana N. Aleksandrova, PhD, Professor, alexandrova_tatyana@mail.ru (Saint Petersburg Mining University, Saint Petersburg, Russia), Cyril O'Connor, Doctor of Engineering, Emeritus Professor, Cyril.OConnor@uct.ac.za (University of Cape Town, Cape Town, South Africa).

The paper was received on 15 April, 2020.

The paper was accepted for publication on 13 May, 2020. 